\title{
EMPIRICAL MODELS FOR POWER AND ENERGY REQUIREMENTS II : A POWERED IMPLEMENT OPERATION IN SERDANG SANDY CLAY LOAM, MALAYSIA
}

\author{
A.F. Kheiralla, A. Yahya*, M. Zohadie, W. Ishak \\ Department of Biological and Agricultural Engineering, Faculty of Engineering, \\ University Putra Malaysia, 43400 Serdang, Selangor D.E., Malaysia
}

Received 27 March 2003, Accepted 28 August 2003

\begin{abstract}
Power and energy requirements were measured with an instrumented tractor for rotary tilling in Serdang sandy clay loam soil. The effects of travel speed and rotor speed upon the measured data were investigated. Power model from orthogonal regression analysis was formulated based on linear and quadratic functions of travel speed and bite length. Fuel consumption model from regression analysis was formulated based on linear tractor PTO power as well as linear equivalent tractor PTO power. Fuel consumption rates predicted by ASAE D497.3 were found to be 25\% to $28 \%$ overestimates of the values predicted by the model developed. However, fuel consumption rates reported by OECD Tractor Test were found to be $1 \%$ to $9 \%$ lower than the fuel consumption rates predicted by the model developed. A comparison of power and energy requirements for both powered and draught implements showed that the disk harrow was the most energy efficient implement in terms of fuel consumption and specific energy followed by the rotary tiller, disk plough and mouldboard. Finally, average PTO power, fuel consumption, wheel slip, wheel power and specific energy for a powered implement are presented.
\end{abstract}

Keywords : Tillage; powered implement, modelling; power and energy requirements

\section{INTRODUCTION}

Malaysian demand for food has been increasing as evidenced by the increasing cost of the imported food. Agricultural production in Malaysia for two past decades has increased, since the implementation of agricultural mechanisation. The introduction of mechanisation in rice cultivation has replaced many highly labour intensive activities making double or triple cropping a reality. This intensive cropping system has enhanced yields. This level of mechanisation requires among other things fast and more timely cultivation.

Powered implements (i.e., rotary tillers) are increasingly used in rice cultivation. Powered implements prepare the seed bed totally different from draught implements. The soil is pulverised

*Corresponding author-email: azmiy@eng.upm.edu.my 
by cutting and chopping action of rotary powered elements. The powered implements give high quality of soil cultivation and uniform incorporation of the soil with plant residues. As far as the quality of the seedbed is concerned, one pass of powered implement is equivalent to several draught implement operations. Charmen et al. ${ }^{1}$ reported that a powered implement that include rigid chisel requires 50\% less energy than a mouldboard plough operating at the same depth. Hendrick $^{2}$ developed a powered rotary chisel with a single rotor and compared the power requirements with that of a rigid chisel. Results show that the powered configuration required $15 \%$ less power. Hendrick assumed power transmission efficiency of $82 \%$ for a powered implement and $49 \%$ for a draught implement. Hoki et al. ${ }^{3}$ tested a powered disk tiller and observed a reduction in total power requirements as well as reduction in draught requirement of about 10\% and they are influenced by travel speed, PTO speed, tillage depth and soil conditions.

Management decisions related to agriculture machinery can affect rice cultivation profit in many ways. Fuel consumption, labour and timeliness are pertinent factors that can contribute to tractor and implement productivity. Therefore, to improve productivity and efficiency it's necessary to have detail information on all aspect of tractor and implement in rice cultivation. The Department of Biological and Agricultural Engineering, University Putra Malaysia has made an initiative to design and develop a data acquisition system to complement built-in tractor instrumentation to provide comprehensive information on tractor and implement field performance. The long range goal is to extensive field testing with instrumented tractor on the aspects of power demand and energy requirements for various agricultural field operations in Malaysia for the development of a useable agricultural machinery management database.

The objective of this paper was to develop empirical models for power and fuel consumption models of a rotary tiller or a powered implement as well as determine power and energy requirements of this implement.

\section{MATERIALS AND METHODS}

Tillage experiments were carried out at the University's farm. The experiments were performed on three 1.05 ha plots for 1999 and 2000 year. These plots were planted to maize before the commencement of tillage studies. Most of the plots varied from nearly level to gently sloping. The area received an average annual precipitation of $207.3 \mathrm{~cm}$. Soil from field was classified by mechanical analysis using pipette method. Soil samples were collected during tillage experiments to determine the average moisture contents. The sampled were weighed and oven dried at $110^{\circ} \mathrm{C}$ for 48 hours. Moisture contents were calculated on a dry weight basis. Cone index values were obtained by taking penetrometer reading for 6 inches depth at one-inch instrument at twelve locations for each travel speed and rotor speed combination subplot. The cone penetrometer used was in accordance with ASAE Standard S313.2 ${ }^{4}$ with cone base of $323 \mathrm{~mm}^{2}$. Table 1 shows soil classification, and $95 \%$ confidence intervals of soil moisture content and cone index for the experiments.

Rotary tiller 36-1550 HOWARD HR39 was used in this experiment for evaluating power and energy requirements over different travel speeds and rotor speeds. This implement is representative 
Table 1 : Soil classification and 95\% confidence intervals of soil cone index and soil moisture content of the fields

\begin{tabular}{cc}
\hline Soil Composition & $\%$ \\
\hline Clay & 43.3 \\
Silt & 9.54 \\
Sand & 38.3 \\
Organic matter & 12.5 \\
\hline Classification & Serdang sandy clay loam \\
\hline Soil properties & $95 \%$ confidence interval \\
Cone Index, kPa & $536 \pm 238$ \\
@ $15-30 \mathrm{~cm}$ & $1028 \pm 382$ \\
Moisture content (d.b), \% & $17.7 \pm 4.0$ \\
\hline
\end{tabular}

of the major tillage implement commonly used in rice cultivation in Malaysia. A $4 \times 3$ factorial design with four levels of travel speeds, three levels of rotor speeds and three replications in two time blocks (years) was employed in the field test. The travel speeds used for a rotary tiller were $3.3,4.2,5.1$ and $6.2 \mathrm{~km} / \mathrm{h}$. These target speeds were obtained by operating the tractor at PTO speed of $540 \mathrm{rpm}$ and adjusting the gear position at four different settings. Rotor speeds of 140, 175 and $200 \mathrm{rpm}$ were maintained at tillage depth of $10 \mathrm{~cm}$. The rotary tiller operation was conducted in a disturbed soil after disking and mouldboard ploughing. In 2000, one of the plots was replaced by a flat plot for conducting validation tests.

The rotary tiller was connected to a $64 \mathrm{~kW}$ Massey Ferguson 3060 (PTO power $51 \mathrm{~kW}$, OECD test No. 61020) for collecting field data on tractor and implement performance during the tillage experiments. The tractor was equipped with an on-board instrumentation system consisted of a factory installed Datatronic instrumentation system and a data acquisition system described by Kheiralla and Yahya ${ }^{5}$. Fuel consumption was measured by means of a micro oval flow meter that was located in the fuel line between fuel filter and injection pump of the tractor. Travel speed was measured by a Doppler radar unit located about midway on the left of the tractor. Two magnetic pickups near tractor engine and near crown wheel of the rear differential unit were used to measure engine speed, wheel speed, respectively. PTO torque was measured by a specially fabricated PTO shaft torque transducer that was located between the tractor PTO and the implement PTO input. Wheels torques was measured by a pair of specially made transducers that were mounted on each side of the rear wheel axles of the tractor. All specially fabricated transducers were calibrated at the start of each season. A command program was developed for the data acquisition system to scan and record transducers signal every second. The stored data in the memory card was down loaded into the computer at the end of the field tests. Tillage power, and energy data taken during the field test were then processed to determine the average and standard deviation of PTO torque, travel speed, rotor speed, tillage depth, fuel consumption, wheel torque, slip, soil moisture content and cone index. This paper the entire draught implements were tested at tillage depth of 10 to $12 \mathrm{~cm}$ and at travel speed of $3,4,5$ and $6 \mathrm{~km} / \mathrm{h}$. The rotary tiller was operated at rotor speed of $140 \mathrm{rpm}$. The average values for PTO torque, travel speed, rotor speed, fuel consumption, wheel torque, slip were used in the statistical analysis. Analysis of covariance, variance, orthogonal regression and linear regression using SAS software package 6 
were used to analyse and develop power and fuel models for rotary tiller. Significance of difference among means was determined using the Duncan's multiple range test. The level probability value was set at 0.05 for all comparisons

\section{RESULTS AND DISCUSSIONS}

\subsection{Power model}

Regression analysis using orthogonal techniques were performed on the power data for the rotary tiller, which showed significant effect of travel speed and rotor speed on power in the analysis of variance (Table 2). Regression coefficients obtained from the proceeding analyses are presented in Table 3. The result shows that the effects of bite length, bite length squared and travel speed on power for rotary tiller were highly significant $(\mathrm{P}<0.01)$ while bite lengthtravel speed interaction was significant $(\mathrm{P}<0.05)$. The following regression equation describes a rotary tiller power within tested range of bite length and travel speed at constant tillage depth of $10 \mathrm{~cm}$ :

$$
\begin{array}{r}
P=-6.7903-1.2593 B+0.0684 B^{2}+9.9205 S-0.3269 B \times S \\
\text { with } \quad R^{2}=0.7948
\end{array}
$$

where $\mathrm{P}$ is the power in $\mathrm{kW} / \mathrm{m}, \mathrm{B}$ is the bite length in $\mathrm{cm}$, and $\mathrm{S}$ is travel speed in $\mathrm{km} / \mathrm{h}$. A three dimensional representation of regression equation 1 is illustrated in Figure 1. This plot

Table 2 : ANOVA for the rotary tiller PTO power

\begin{tabular}{lrrc}
\hline Source & \multicolumn{1}{c}{ SS } & MS & F-value \\
\hline Year & 9.3672 & 9.3672 & $1.20 \mathrm{NS}$ \\
Rotor & 360.6942 & 180.3471 & $23.24^{* *}$ \\
Speed & 1471.0934 & 490.3644 & $63.20^{* *}$ \\
Rotor $\times$ speed & 38.6719 & 6.4453 & $0.83 \mathrm{NS}$ \\
Error & 457.7320 & 7.7582 & \\
\hline
\end{tabular}

** Significant at $1 \%$ probability level

NS Not significant

Table 3 : Orthogonal regression analysis for the rotary tiller power in Serdang sandy clay loam soil (1999 and 2000)

\begin{tabular}{clccc}
\hline Power & \multicolumn{2}{c}{ Regression coefficients $\uparrow$} & Probability & $\mathrm{R}^{2}$ \\
& symbol & value & $(\mathrm{P})$ & 0.7922 \\
$\mathrm{~kW} / \mathrm{m}$ & $\mathrm{C}_{0}$ & -6.7903 & & \\
& $\mathrm{C}_{1}(\mathrm{~B})$ & -1.2593 & 0.0001 & \\
& $\mathrm{C}_{2}\left(\mathrm{~B}^{2}\right)$ & 0.0684 & 0.0019 & \\
& $\mathrm{C}_{3}(\mathrm{~S})$ & 9.9205 & 0.0001 & \\
& $\mathrm{C}_{4}\left(\mathrm{~S}^{2}\right)$ & 0.0000 & 0.0000 & \\
& $\mathrm{C}_{5}(\mathrm{~B} \times \mathrm{S})$ & -0.3269 & 0.0189 & \\
\hline
\end{tabular}

$\dagger$ Statistically insignificant $(\mathrm{P}>0.05)$ coefficients are entered as zero 


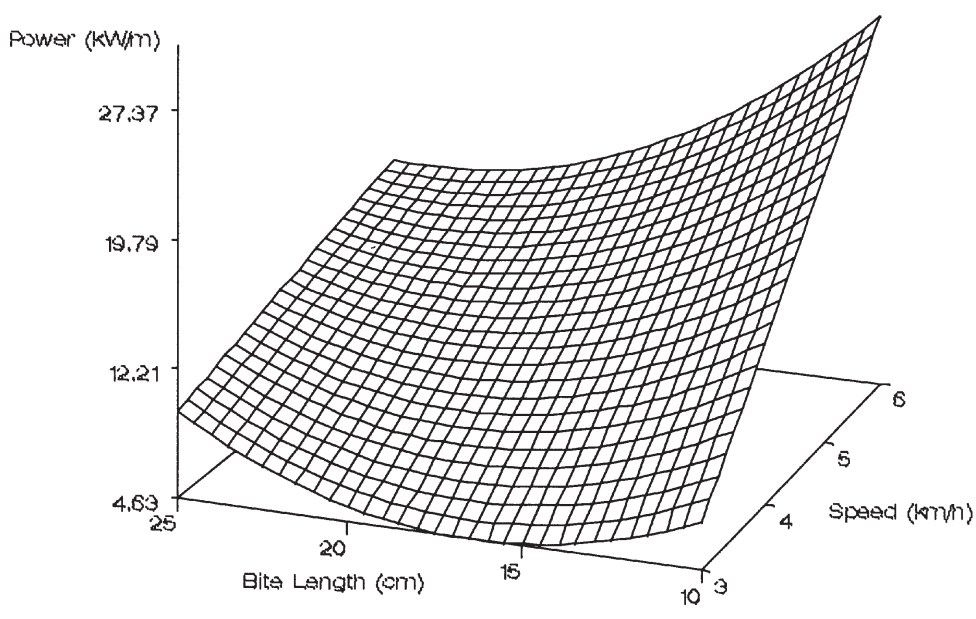

Figure 1 : Three-dimensional for rotary tiller power model

shows increasing power of the rotary tiller with increasing travel speed and decreasing bite length (i.e increasing rotor speed) in Serdang sandy clay loam soil.

Many important parameters affect power of a rotary tiller including bite length, depth of cut, rotor speed, blade shape and soil type and conditions. Significant laboratory work in rotary tillers had been reviewed in a concisely series of papers by Hendrick and Gill ${ }^{7-11}$ which include attempts at finding the optimum blade parameters as well as power required. However, information is lacking in ASAE Standard D497.3 ${ }^{12}$ regarding power requirements of a rotary tiller. Rotary tiller power versus bite at three rotor speeds is shown in Figure 2. The increase in power was due to the increased bite length as a result of the increased travel speed. Similar trend was also observed by Chamen et al. ${ }^{1}$ and Hendrick and Gill ${ }^{9}$. In general, the rotary tiller operation is largely dependent upon the rotor speed and the travel speed of the tractor. Also, rotor speed in

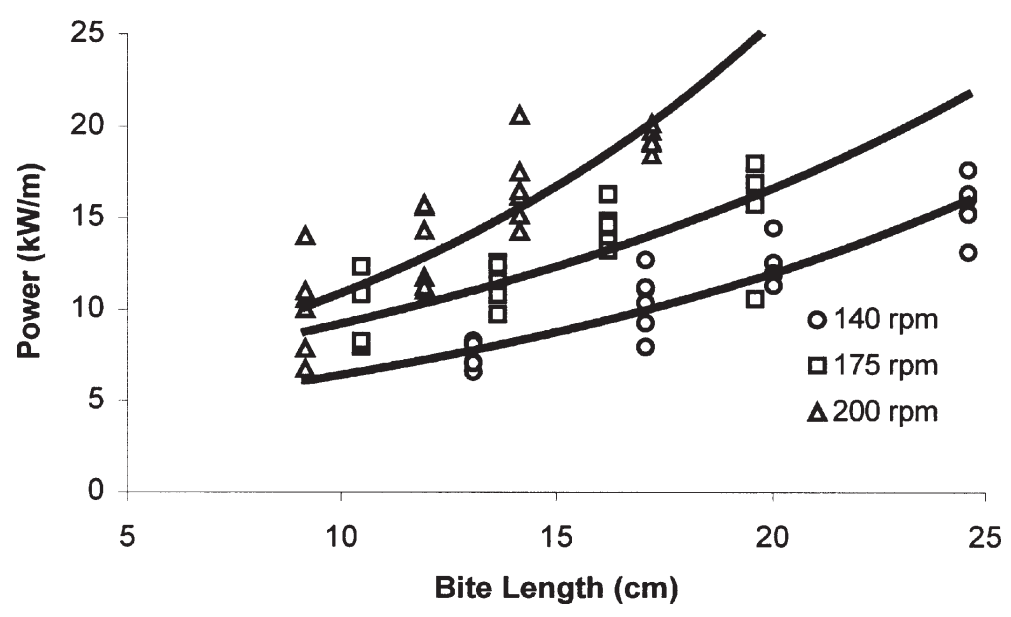

Figure 2: Rotary tiller PTO power at three tested rotor speed 
combination with travel speed determines the effective bite length of the implement. Increasing the bite length reduces the severity of tillage effect causing less aggregation size and vise versa. The knowledge of these relationships may permit to optimise between work rate and energy required in order to maintain adequate seedbed quality. A high travel speed is desirable in order to maximise work rate, but the high rotor speeds, which would be necessary to maintain bite length and tillage affect at acceptable levels could consume disproportionate amount of energy.

\subsection{Fuel consumption model}

Regression analysis was performed on fuel consumption data of a rotary tiller, which showed a significant effect of PTO power on fuel consumption. Regression result for the rotary tiller exhibits a linear relationship between fuel consumption rate and PTO power with coefficient of determination equal to 0.8024 . The fuel consumption for the rotary tiller is best expressed by the following regression equation:

$$
F C=0.2156 P_{\text {PTO }}+6.2347 \text { with } \quad \mathrm{R}^{2}=0.8024
$$

where $\mathrm{P}_{\mathrm{PTO}}$ is the PTO power in $\mathrm{kW}$. The fuel consumption for a rotary tiller operation increased as the tractor PTO power is increased. It varied from 8.80 to $12.67 \mathrm{~L} / \mathrm{h}$ as the PTO power is increased from 11.92 to $29.89 \mathrm{~kW}$. Similarly, regression analysis was performed to determine fuel consumption model for a rotary tiller based on fuel consumption and calculated total equivalent power. The total equivalent power in regression analysis includes PTO power and equivalent PTO power converted from the wheel or axle power. Regression result for a rotary tiller in Figure 3 reveals a linear relationship between fuel consumption rate and equivalent PTO power with coefficient of determination equal to 0.8028 . The fuel consumption for the rotary tiller is best described by following regression model;

$$
F C=0.1882 P_{E Q}+5.2422 \text { with } \quad \mathrm{R}^{2}=0.8028
$$

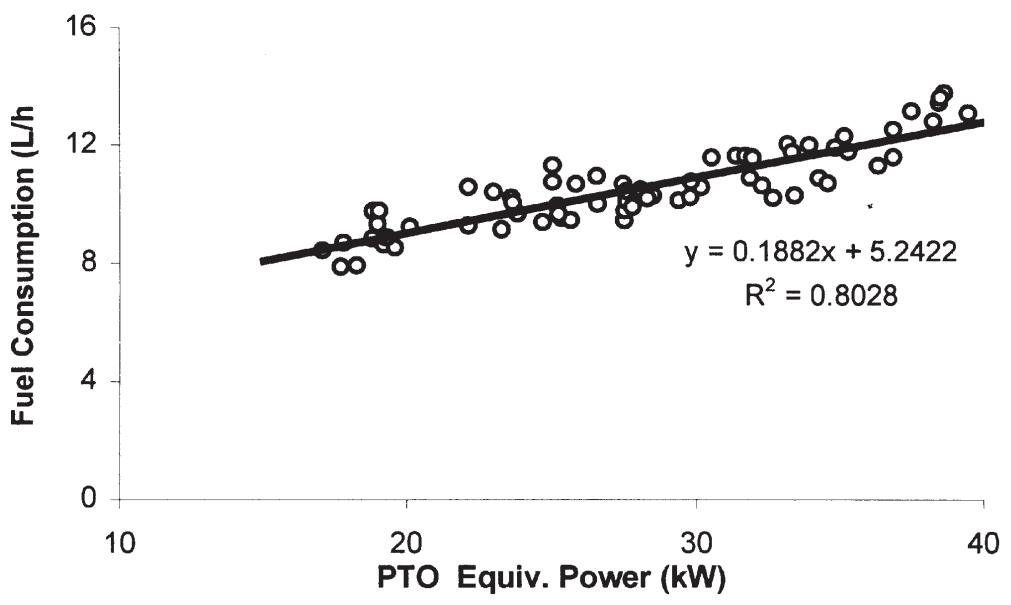

Figure 3 : Rotary tiller fuel consumption model 
where $\mathrm{P}_{\mathrm{EQ}}$ is the equivalent $\mathrm{PTO}$ power in $\mathrm{kW}$. The fuel consumption for rotary tiller operation increased as the tractor equivalent PTO power is increased. It varied from $8.80 \mathrm{~L} / \mathrm{h}$ to 12.67 $\mathrm{L} / \mathrm{h}$ as the PTO power is increased from $18.65 \mathrm{~kW}$ to $38.77 \mathrm{~kW}$.

The Nebraska Tractor Test and OECD Tractor Test are two recognised standards that constitute a large body of information on tractor performance. The OECD Tractor test is more extensive than the Nebraska Tractor Test and provides more complete test performance report on the tractor. The fuel consumption model by ASAE Standard D497.3 ${ }^{12}$ is given as follows:

$$
F C=2.64 X+3.91-0.203 \sqrt{738 X+173}
$$

where $\mathrm{FC}$ is the fuel consumption in $\mathrm{L} / \mathrm{kWh}, \mathrm{X}$ is the ratio of equivalent PTO power required by operation divided by the maximum PTO power. The predictions of tractor's fuel consumption by this fuel consumption model is generally $15 \%$ higher than the reported magnitudes by the Nebraska Tractor Test to reflect losses of fuel efficiency during field operations.

A comparisons between the predicted output by fuel consumption model developed for Massey Ferguson 3060 tractor with a rotary tiller, the predicted output from ASAE Standard D497.3 and the actual magnitudes from OECD Standard Test No. 6102 of the tractor is illustrated in Table 4. The formulate model was made for the rotary tiller at standard PTO speed of $540 \mathrm{rpm}$ that is similar to operating PTO speed of the test tractor under the varying power and fuel consumption in the Nebraska Tractor Test. The fuel consumption rates predicted for the rotary tiller by ASAE Standard equation were 25\% to $28 \%$ higher than the fuel consumption rates predicted by the fuel consumption model. Such discrepancies in magnitudes were expected since the ASAE Standard equation was developed for tractors of sizes $100 \mathrm{~kW}$ to more that are commonly used in USA as compared to tractors of sizes $30 \mathrm{~kW}$ to $60 \mathrm{~kW}$ that are more popular in Asia. Differences in tractor sizes and models lead to variations in fuel efficiencies and consequently produce different magnitudes of fuel consumption. Furthermore, ASAE Standard equation was made to give the predicted magnitude of fuel consumption of $15 \%$ higher than the actual magnitude for the tractor. The fuel consumption rates reported by the OECD Tractor Test were $1 \%$ to $9 \%$ lower than the fuel consumption predicted by the fuel consumption model. These small variations were due to field conditions losses and variability. Again, the predicted fuel consumption rates by model developed were within the acceptable reported fuel consumption range by OECD Tractor Test.

Table 4 : Comparisons of a rotary tiller fuel model with ASAE Standard and OECD Tractor Test at standard PTO speed of $540 \mathrm{rpm}$

\begin{tabular}{|c|c|c|c|c|c|c|c|c|}
\hline \multirow{2}{*}{$\begin{array}{l}\text { Rotor } \\
\text { (rpm) }\end{array}$} & \multirow{2}{*}{$\begin{array}{r}\text { Speed } \\
(\mathrm{km} / \mathrm{h})\end{array}$} & \multicolumn{2}{|c|}{ Fuel model } & \multirow{2}{*}{$\begin{array}{c}\text { Load } \\
\text { Ratio } \\
(\mathrm{X})\end{array}$} & \multicolumn{2}{|c|}{ ASAE Standard } & \multicolumn{2}{|c|}{ OECD Test } \\
\hline & & $\begin{array}{c}\mathrm{P}_{\mathrm{EQ}} \\
(\mathrm{kWh})\end{array}$ & $\begin{array}{c}\mathrm{FC} \\
(\mathrm{L} / \mathrm{kWh})\end{array}$ & & $\begin{array}{l}\text { F.C } \\
(\mathrm{L} / \mathrm{kWh})\end{array}$ & $\begin{array}{r}\text { Error } \\
(\%)\end{array}$ & $\begin{array}{l}\text { F.C } \\
(\mathrm{L} / \mathrm{kWh})\end{array}$ & $\begin{array}{c}\text { Error } \\
(\%)\end{array}$ \\
\hline 140 & $3-6$ & $18.65-33.42$ & $0.469-0.345$ & $.37-0.67$ & $0.599-0.445$ & $27-25$ & $0.426-0.333$ & $(-9)-(-2)$ \\
\hline 175 & $3-6$ & $20.42-33.69$ & $0.448-0.343$ & $0.42-0.67$ & $0.570-0.433$ & $27-25$ & $0.411-0.332$ & $(-8)-(-3)$ \\
\hline 200 & $3-6$ & $22.18-38.77$ & $0.424-0.323$ & $0.44-0.77$ & $0.543-0.416$ & $28-26$ & $0.392-0.321$ & $(-7)-(-1)$ \\
\hline
\end{tabular}




\subsection{Validation of models}

The developed power and fuel consumption models for the rotary tiller were tested against additional field data for the purpose of the validation. This collected data was not included in the regression analysis. Result for regression between predicted and measured power indicates good power prediction for the rotary tiller with resultant slope of 0.9707 (i.e., closed to 1) and coefficient of determination equal to 0.9160 (Table 5). Thus, regression result suggests that predicted power for the rotary tiller was $2.93 \%$ lower than the measured power magnitudes. Similarly, result for regression between predicted and measured fuel consumption shows good fuel consumption prediction for the rotary tiller with resultant slope of 1.0340 (i.e., closed to 1) and coefficient of determination equal to 0.8928 (Table 5). Thus, the regression result suggests that fuel consumption for the rotary tiller was $3.40 \%$ higher than measured fuel consumption magnitudes. Considering the field variability, the validation for draught and fuel consumption models for the rotary tiller was acceptable. Consequently, power and fuel consumption could be successfully predicted with respective models for the rotary tiller.

Table 5 : Results for regression between predicted and measured power or fuel consumption for the rotary tiller

\begin{tabular}{lccc}
\hline Model & \multicolumn{2}{c}{ Regression coefficients $\dagger$} \\
& Slope & Probability $(\mathrm{P})$ & $\mathrm{R}^{2}$ \\
\hline Power & 0.9707 & 0.0001 & 0.9160 \\
Fuel & 1.0340 & 0.0001 & 0.8928 \\
\hline
\end{tabular}

$\dagger$ Note that the intercept was estimated to zero $(\mathrm{P}>0.05)$

\subsection{Power and energy requirements}

Summary power and energy for the rotary tiller as a powered draught implement in Serdang sandy clay loam soil obtained during 1999 and 2000 is presented in Table 6. Eight parameters were measured or calculated to determine the power and energy requirements for the rotary tiller. The tillage depth of a rotary tiller was set constant at $10 \mathrm{~cm}$ through out test. Maximum PTO power with a rotary tiller was $29.89 \mathrm{~kW}$ at rotor speed of $200 \mathrm{rpm}$ when operating at travel speed of $6.2 \mathrm{~km} / \mathrm{h}$, which coincidentally resulted with a bite length of $17.20 \mathrm{~cm}$. The corresponding fuel consumption was $13.85 \mathrm{~L} / \mathrm{h}$, wheel power was $8.53 \mathrm{~kW}$ and specific energy was 37.97 $\mathrm{kWh} / \mathrm{ha}$. Minimum PTO power was $11.92 \mathrm{~kW}$ at rotor speed of $140 \mathrm{rpm}$ when operating at travel speed of $3.3 \mathrm{~km} / \mathrm{h}$, which resulted with a bite length of $13.09 \mathrm{~cm}$. The fuel consumption was $16.48 \mathrm{~L} / \mathrm{h}$, wheel power was $6.46 \mathrm{~kW}$, and specific energy was $28.39 \mathrm{kWh} / \mathrm{ha}$. Generally, power and energy requirements of a rotary tiller were affected by rotor speed and travel speed. The PTO power increased considerably with increase bite length, when travel speed was increased while maintaining the rotor speed. Similar trend was also observed for the wheel power but as for fuel consumption a reverse trend was obtained. Again, the PTO power and specific energy increased with a decrease in bite length when the rotor speed was increased while maintaining the travel speed. Small magnitude of wheel slip in the range of 3 to $4 \%$ and wheel power in the range of 6.46 to $8.53 \mathrm{~kW}$ were obtained for this rotary tilling operations. Rotor speed of 
Table 6 : Summary of power and energy requirements for the powered implement (rotary tiller) in Serdang sandy clay loam soil

\begin{tabular}{cccccccc}
\hline $\begin{array}{c}\text { Rotor } \\
\text { speed } \\
(\mathrm{rpm})\end{array}$ & $\begin{array}{c}\text { Speed } \\
(\mathrm{km} / \mathrm{h})\end{array}$ & $\begin{array}{c}\text { Bite } \\
\text { length } \\
(\mathrm{cm})\end{array}$ & $\begin{array}{c}\text { PTO } \\
\text { power } \\
(\mathrm{kW})\end{array}$ & $\begin{array}{c}\text { F.C } \\
(\mathrm{L} / \mathrm{ha})\end{array}$ & $\begin{array}{c}\text { Wheel } \\
\text { slip } \\
(\%)\end{array}$ & $\begin{array}{c}\text { Wheel } \\
\text { power } \\
(\mathrm{kW})\end{array}$ & $\begin{array}{c}\text { Specific } \\
\text { energy } \\
(\mathrm{kWh} / \mathrm{h})\end{array}$ \\
\hline 140 & 3.3 & 13.09 & 11.92 & 16.48 & 3 & 6.46 & 28.39 \\
140 & 4.3 & 17.06 & 16.26 & 14.71 & 3 & 7.49 & 29.59 \\
140 & 5.1 & 20.23 & 19.19 & 13.58 & 4 & 8.65 & 30.36 \\
140 & 6.2 & 24.60 & 23.38 & 11.20 & 4 & 9.64 & 29.69 \\
\hline 175 & 3.3 & 10.49 & 14.36 & 18.33 & 3 & 6.25 & 34.20 \\
175 & 4.3 & 13.65 & 17.96 & 15.34 & 3 & 8.20 & 32.69 \\
175 & 5.1 & 16.20 & 22.27 & 13.86 & 3 & 8.62 & 34.37 \\
175 & 6.2 & 19.60 & 24.21 & 11.68 & 4 & 9.10 & 30.75 \\
\hline 200 & 3.3 & 9.17 & 15.57 & 19.04 & 3 & 6.35 & 37.06 \\
200 & 4.3 & 11.94 & 20.60 & 16.05 & 3 & 7.29 & 37.49 \\
200 & 5.1 & 14.16 & 25.81 & 15.05 & 4 & 9.34 & 39.80 \\
200 & 6.2 & 17.20 & 29.89 & 13.85 & 4 & 8.53 & 37.97 \\
\hline
\end{tabular}

$140 \mathrm{rpm}$ and travel speed of $6.2 \mathrm{~km} / \mathrm{h}$ combination exhibited minimum fuel consumption of $11.20 \mathrm{~L} / \mathrm{ha}$ at effective bite length of 24.6 and specific energy of $29.69 \mathrm{kWh} / \mathrm{ha}$. Hendrik and Gill $^{7-9}$ stated that low rotary speed and forward speed rotation are necessary to reduce draught and power requirement of rotary tillage tools. However, rotary speed that is too slow causes excessive variation in tillage depth because of the blade kinematics ${ }^{13}$. A faster rotor speed disturbs more soil than necessary and requires excessive power ${ }^{9}$. Hendrik ${ }^{2}$ suggested a practical lower limit of the velocity ratio of peripheral velocity of blade tip to forward velocity of machine to be 2.5 .

Table 7 shows the comparison of power and energy requirements for both draught and powered implement. Mouldboard plough, disk plough and disk harrow are categorised as draught implement while a rotary tiller was categorised as powered implement. Four parameters were measured or calculated to quantify the power and energy requirement of the various implement. The following comparisons of power and energy requirement between draught and powered implement could be conservative due to different fact that both implement types adopt different soil cutting techniques. The specific energy for draught and powered was calculated by Shinners et al. ${ }^{14}$ as follows:

Table 7 : A comparison of power and energy requirements for draught and powered implements at tillage depth of 10 to $12 \mathrm{~cm}$

\begin{tabular}{lcccc}
\hline \multicolumn{1}{c}{ Implement } & F.C (L/ha) & $\begin{array}{c}\text { Wheel slip } \\
(\%)\end{array}$ & $\begin{array}{c}\text { Wheel power } \\
(\mathrm{kW})\end{array}$ & $\begin{array}{c}\text { Specific energy } \\
(\mathrm{kWh} / \mathrm{ha})\end{array}$ \\
\hline Mouldboard & $15.74^{\mathrm{A}}$ & $11.3^{\mathrm{B}}$ & $15.66^{\mathrm{B}}$ & $43.84^{\mathrm{A}}$ \\
Disk plough & $14.87^{\mathrm{B}}$ & $10.3^{\mathrm{B}}$ & $16.59^{\mathrm{C}}$ & $42.13^{\mathrm{A}}$ \\
Disk harrow & $6.99^{\mathrm{D}}$ & $22.0^{\mathrm{A}}$ & $22.98^{\mathrm{A}}$ & $18.50^{\mathrm{C}}$ \\
Rotary tiller & $14.07^{\mathrm{C}}$ & $3.1^{\mathrm{D}}$ & $8.07^{\mathrm{D}}$ & $29.23^{\mathrm{B}}$ \\
LSD $_{(\mathrm{P}<0.05)}$ & 0.66 & 1.3 & 0.71 & 1.90 \\
\hline
\end{tabular}

Means followed with same superscript letter within a column not significantly different at $\mathrm{P}<0.05$ according to Duncan's multiple range test (SAS, 1996). 


$$
S E=\frac{\left|\frac{p_{P T O}}{\mu_{P T O}}+\frac{p_{D B}}{\mu_{D B}}\right|}{s \times W} \times 10
$$

where SE is the specific energy in $\mathrm{kWh} / \mathrm{ha}, \mathrm{P}_{\mathrm{PTO}}$ is the PTO power in $\mathrm{kW}, \mu_{\mathrm{PTO}}$ is the PTO power transmission efficiency, assumed to be $0.82, \mathrm{P}_{\mathrm{DB}}$ is the drawbar power in $\mathrm{kW}, \mu_{\mathrm{DB}}$ is the drawbar power transmission efficiency, assumed to be $0.49, \mathrm{~s}$ is the travel speed in $\mathrm{km} / \mathrm{h}$ and $\mathrm{W}$ is the width in $\mathrm{m}$.

The mean fuel consumption, wheel slip, wheel power and specific energy were significantly $(\mathrm{P}<0.05)$ affected by implement types. The mean fuel consumption of a mouldboard plough and a disk plough were $12 \%$ and $6 \%$, respectively, higher than that of a rotary tiller. However, the fuel consumption of a disk harrow was $37 \%$ lower than that of a rotary tiller. Likewise, the average specific energy of a mouldboard plough and a disk plough were 50\% and $44 \%$, respectively, higher than of a rotary tiller. However, the specific energy of a disk harrow was $37 \%$ lower than that of rotary tiller. Similarly, Chamen et al. ${ }^{1}$ reported that the specific energy for their rotary digger with rigid chisel tine behind on cereal crops was $50 \%$ less than the mouldboard plough operating at same tillage depth. According to them, the significant a increase in fuel consumption and specific energy for a rotary tiller over a disk harrow could be due excessive soil pulverisation by the rotary tiller within a single pass for seedbed preparation. Chamen et al. ${ }^{15}$ encountered similar relative differences in specific energy during similar trails with PTO driven harrow on clay soil types. The mean wheel slip of a mouldboard plough, disk plough and disk harrow were $265 \%, 232 \%$ and $609 \%$, respectively, higher than that of a rotary tiller. Also, the mean wheel power of a mouldboard plough, disk plough and disk harrow were $92 \%, 104 \%$ and $184 \%$, respectively, higher than that of a rotary tiller. The results revealed that the rotary tiller was more energy efficient than the mouldboard plough and disk plough on the basis of fuel consumption and specific energy. As powered implement, the soil cutting power comes directly from tractor's PTO shaft with no losses due wheel slippage and tyre rolling resistance as compared to any draught implement. Consequently, the transmission power through tractor's PTO shaft for the powered implement is more efficient than the transmitting power through traction wheels for the draught implement. Zoz ${ }^{16}$, Taylor and Burt ${ }^{17}$, Hendrik ${ }^{2}$ and Shinners et al. ${ }^{14}$ estimated that overall average power transmission efficiency was $82 \%$ for a powered implement and $49 \%$ for a draught implement. However, the rotary tiller was less energy efficient than the disk harrow in terms fuel consumption and specific energy. The rotary tiller could produce a seedbed in only one pass; thereby reducing unwanted seedbed compaction and consequent energy losses. Few passes of disk harrow were required to obtain the equivalent quantity of seedbed produce by a rotary tiller. Furthermore, wheel slip and wheel power of positive draught implement were 3.5 to 7 times and 2 to 3 times, respectively, of that of powered implement. Reduced wheel slip and wheel power could reduce soil compaction and allow operation to be performed in more difficult traction conditions. Besides reducing soil compaction, the rotary tiller increase soil pulverisation and crop residue incorporation, thereby improving field productivity. Thus, a rotary tiller was not only energy efficient, but also more productive as compared to a mouldboard plough and a disk plough. The larger torque fluctuations were 
found to develop by rotor tiller at rotor speed of $250 \mathrm{rpm}$ and travel speed of $3.3 \mathrm{~km} / \mathrm{h}$ during field testing that caused a noise problem to Doppler radar on the tractor for accurate travel speed measurements. Wismer et al. ${ }^{18}$ mentioned that forward thrust given by powered implement demand better control on the tractor steering and three point hitch to the tractor and could be harmful to the tractor's drive train.

\section{CONCLUSIONS}

1. Power model for the rotary tilling was formulated based on travel speed and bite length using an orthogonal regression procedure. The power model was formulated as follows:

$$
\mathrm{P}=-6.7903-1.2593 \mathrm{~B}+0.0684 \mathrm{~B}^{2}+9.9205 \mathrm{~S}-0.3269 \mathrm{~B} \times \mathrm{S}
$$

2. Fuel consumption model of rotary tilling in Serdang sandy clay loam soil was formulated based on PTO power as well as equivalent PTO power. The fuel models were formulated as follows:

$$
\begin{aligned}
& \mathrm{FC}=0.2156 \mathrm{P}_{\mathrm{PTO}}+6.2347 \\
& \mathrm{FC}=0.1882 \mathrm{P}_{\mathrm{EQ}}+5.2422
\end{aligned}
$$

3. The fuel consumption rates predicted by ASAE D497.3 were found to be $25 \%$ to $28 \%$ overestimated compared to the fuel consumption predicted by the models developed. However, fuel consumption rates reported by OECD Tractor Test were found to be $1 \%$ to $9 \%$ underestimated compared to fuel consumption rates predicted by models developed.

4. The validation test revealed that predicted power for the rotary tiller was $2.93 \%$ lower than the measured power magnitudes, while predicted fuel consumption rates were $3.4 \%$ higher than the measured fuel consumption magnitudes. Consequently, the implement power and fuel consumption could be successfully predicted by the models with good accuracy.

5. Rotor speed of $140 \mathrm{rpm}$ and travel speed of $6.2 \mathrm{~km} / \mathrm{h}$ combination in rotary tiller operation exhibited minimum fuel consumption of $11.20 \mathrm{~L} / \mathrm{ha}$ at effective bite length of 24.6 and specific energy of $29.69 \mathrm{kWh} / \mathrm{ha}$.

6. The mean fuel consumption of a mouldboard plough and disk plough were $12 \%$ and $6 \%$, respectively, higher than that of a rotary tiller. However, the fuel consumption of a disk harrow was $37 \%$ lower than that of a rotary tiller. Similarly, mean specific energy of a mouldboard plough and a disk plough were $50 \%$ and $44 \%$, respectively, higher than of a rotary tiller. However, the specific energy of a disk harrow was $37 \%$ lower than that of a rotary tiller. Consequently, the disk harrow was the most energy efficient implement in terms of fuel consumption and specific energy followed by the rotary tiller, disk plough and mouldboard.

\section{ACKNOWLEDGEMENTS}

This research project is classified under RM7 IRPA Project No. 01-02-04. The authors are very grateful to the Ministry of Science, Technology and the Environment of Malaysia for granting the fund for this research project. 


\section{REFERENCES}

1. Chamen, W.C.T., Cope, R.E. and Patterson, D.E. (1979), J. Agric. Engng. Res., vol. 24, pp. 301-308.

2. Hendrick, J.G., (1980), Transactions of the ASAE, vol. 23, no. 6, pp. 1349-1352.

3. Hoki, M., Burkhardt, T.H., Wilkinson, R.H. and Tanoue, T. (1988), Transactions of the ASAE, vol. 31, no. 5, pp. 1355-1360.

4. ASAE, 1997b. S313.2., Soil cone penetrometer. In: Hahn, R.H., Purschwitz, M.A., and Rosentreter, E.E. (eds.), ASAE Standards 1997, 44th edition, ASAE, St. Joseph, MI, pp. 821-822.

5. Kheiralla, A.F. and Azmi Y., (2001), Pertanika J. Sci. \& Technol., vol. 9, no. 2, pp. 51-67.

6. SAS. (1996), SAS User's Guide: Statistics. Statistical Analysis System Inc., NC.

7. Hendrick, J.G. and Gill, W.R. (1971a), Transactions of the ASAE, vol. 14, no. 4, pp. 669-674, 683.

8. Hendrick, J.G. and Gill, W.R. (1971b), Transactions of the ASAE, vol. 14, no. 4, pp. 675678.

9. Hendrick, J.G. and Gill, W.R. (1971c), Transactions of the ASAE, vol. 14, no. 4, pp. 679683.

10. Hendrick, J.G. and Gill, W.R. (1974), Transactions of the ASAE, vol. 17, no. 1, pp. 4-7.

11. Hendrick, J.G. and Gill, W.R. (1978), Transactions of the ASAE, vol. 21, no. 4, pp. 658-660.

12. ASAE, 1997a. D497.3. Agricultural machinery management data. In: Hahn, R.H., Purschwitz, M.A., and Rosentreter, E.E. (eds.), ASAE Standards 1997, 44th edition, ASAE, St. Joseph, MI, pp. 363-370.

13. Hendrick, J.G. and Gill, W.R. (1976), Transactions of the ASAE, vol. 19, no. 2, pp. 230-233.

14. Shinners K.J., Alcock, R. and Wilkes, J.M. (1990), Transactions of the ASAE, vol. 33, no. 2, pp. 400-404.

15. Chamen, W.C.T., Cope, R.E., Longstaff, D.J. and Richardson, C.D. (1994), The energy efficiency of seedbed production following mouldboard ploughing. Proceedings of the $13^{\text {th }}$ International Conference of International Soil Tillage Research Organization, Aalborg, Denmark, pp. 1227-1232. (24-29 July 1994)

16. Zoz, F.M., (1970), Transactions of the ASAE, vol. 15, pp. 249-255.

17. Taylor, J.H. and Burt, E.C. (1975), Transactions of the ASAE, vol. 18, no. 1, pp. 3-6.

18. Wismer, R.D., Wegscheid, E.L. , Luth, H.J. and Romig, B.E. (1968), Energy application in tillage and earthmoving. SAE Paper No. 69, p. 230. 